DOI https://doi.org/10.18551/rjoas.2021-02.03

\title{
THE EFFECT OF CLONES AND PLANT SPACING ON THE GROWTH AND YIELDS OF STEVIA (STEVIA REBAUDIANA BERTONI L.)
}

\author{
Lestari*, Abdurrakhman, Herwati Anik, Supriyono, Yulaikah Sri \\ Balai Penelitian Tanaman Pemanis and Serat (BALITTAS), Malang, Indonesia \\ *E-mail: lestari226@gmail.com
}

\begin{abstract}
Stevia (Stevia rebaudiana Bertoni $\mathrm{L}$ ) is one of the potential alternative commodities for noncaloric sugar producers, so it is safe for health. However, until today, information on stevia cultivation technology has not been widely reported. This research aimed to determine the effect of clones and plant spacing on stevia growth. It was carried out in the Experimental Garden (EG) of Cobanrondo, Balai Penelitian Tanaman Pemanis and Serat (Balittas) ${ }^{1}$, at an altitude of $1450 \mathrm{~m}$ above sea level, from September to November 2012. The research was arranged in a factorial using a randomized block design with three replications. The first factor was the stevia clones from Bogor, consisting of 2 types of clones: wide-leaf clones and narrow-leaf clones. The second factor is the plant spacing composed of 2 levels: a narrow plant spacing $(25 \mathrm{~cm} \times 25 \mathrm{~cm})$ and a wide plant spacing $(40 \mathrm{~cm} \times 40 \mathrm{~cm})$. The plot size was 2 $\mathrm{m} \times 2 \mathrm{~m}$. Observations were made on plants aged 14 days after planting (DAP), 28 DAP, and 46 DAP on plant height, canopy width, number of leaves, dry weight of leaves, and dry weight of leafless stover. The research results showed that plant spacing affected plant height at 46 DAP and canopy width at 28 and 46 DAP. Narrow spacing produces taller plants than wide plant spacing, whereas clones affected plant height at 28 DAP and 46 DAP and the number of leaves at 46 DAP. Plant spacing, varieties, and interactions did not affect dry leaf weight and leafless stover weight at 46 DAP. Thus, stevia clones, both narrow and wideleaf, are recommended at a narrow plant spacing.
\end{abstract}

\section{KEY WORDS}

Stevia, clones, yields, plant spacing.

The need for sweeteners in Indonesia, especially sugar, increases both in the industrial and household sectors. Badan Pusat Statistik (BPS) ${ }^{2}$ reports that the national sugarcane production in 2012 reached 2.3 million tons/year, while the total national sugar consumption needs to go 5.2 million tons/year. This figure consists of sugar demand for the industry of 2.5 million tons/year and the need for direct household consumption of 2.7 million tons/year. Meanwhile, the industry's sugar supply can only be fulfilled around 2.1 million tons/year (SWA, 2012). It means that the fulfillment of sugar needs for both households and industry is still lacking. Thus, efforts are needed to meet national sugar demands by seeking other sugar sources such as stevia (Stevia rebaudiana Bertoni L.).

Stevia rebaudiana Bertoni L. belongs to the Asteraceae tribe. Their botanical and morphological properties are annual shrubs with many branches. They can grow up to $60 \mathrm{~cm}$ to $90 \mathrm{~cm}$, have elongated single leaves, and have slight ridges and leaf holder facing (Shock, 1982). The stevia plant has a leaf length of $7-15 \mathrm{~cm}$ and a leaf width of $3-5 \mathrm{~cm}$. It looks thin on the stem, and the trichomes are curly (Syarif, 1982). Stevia has two (2) root systems, namely fine roots near the soil surface and dense roots with thick and coarse roots penetrating the soil (Sumida, 1980).

Stevia is non-carcinogenic and non-calorie in nature, so it is perfect for people with blood sugar disease. Stevia sugar is produced from the leaves that make sweeteners, namely stevioside and rebausida $A$., which have a 200 times greater sweetness than cane

\footnotetext{
${ }^{1}$ Indonesian Sweetener and Fiber Crops Research Institute (ISFCRI).

${ }^{2}$ Central Bureau of Statistics.
} 
sugar. Thus, stevia sugar is suitable for meeting industrial sugar consumption, both food and beverage.

The production of stevia leaves is made to increase continuously. Concerning expanding the production and quality of stevia leaves, several research efforts are needed. One of the actions that can be taken is to adjust the optimal plant spacing. Plant spacing will affect plant density in units of area. Too tight plant spacing will inhibit plant growth, while too wide plant spacing will reduce perennial plants' number and provide opportunities for weeds to grow.

With two (2) stevia clones from Bogor, we examined the optimal spacing and the growth and adaptability of stevia to the agroecological environment in Coban Rondo, Malang.

This study aimed to determine the effect of the plant spacing and differences in stevia clones on the growth and production of stevia plants. Thus, the study would provide information on optimal population density and the maximum number of stevia leaves as sweeteners, especially in agroecological development locations such as in Cobanrondo.

\section{MATERIALS AND METHODS OF RESEARCH}

This research was conducted from September to November 2012 at the EG Cobanrondo, Malang, at an altitude of $1450 \mathrm{~m}$ above sea level (asl). The study was arranged in a factorial using a randomized block design with three replications. The first factor was the stevia clones from Bogor, consisting of 2 types of clones: wide-leaf clones and narrow-leaf clones. The second factor is the plant spacing composed of 2 levels: a narrow plant spacing $(25 \mathrm{~cm} \times 25 \mathrm{~cm})$ and a wide plant spacing $(40 \mathrm{~cm} \times 40 \mathrm{~cm})$. The plot size was $2 \mathrm{~m} \times 2 \mathrm{~m}$.

The stevia planting material was from 4-week old cuttings collected from Kebun Balai Penelitian Tanaman Rempah and Obat-Obatan (Balittro) ${ }^{3}$, Bogor. Cuttings were used because they were proven to be more uniform and faster to supply than seeds (generative) (Yusmaini and Suharsih, 2008).

Plant maintenance included fertilizing, watering, and controlling pests and diseases. NPK fertilization at a dose of $1 \mathrm{~g}$ urea, $1 \mathrm{~g} \mathrm{TSP}$, and $1 \mathrm{~g} \mathrm{KCL}$ per plant and organic fertilizer was given along with soil cultivation. Meanwhile, watering and pest and disease control were carried out following field conditions.

Observation parameters included plant height, canopy width, number of leaves, dry weight of leaves, and leafless stover weight. The data obtained were analyzed using a randomized block design a significance level of $5 \%$ and continued with the $5 \%$ Duncan test.

\section{RESULTS AND DISCUSSION}

Table 1 indicates the effect of clones and plant spacing on several growth parameters and stevia yields. It shows that plant spacing affects plant height at 46 DAP and canopy width at $28 \mathrm{DAP}$ and 46 DAP. A narrow plant spacing $(25 \mathrm{~cm} \times 25 \mathrm{~cm})$ produced taller plants than the wide plant spacing $(40 \mathrm{~cm} \times 40 \mathrm{~cm})$.

The stevia plant is a short-day plant. This plant will flower more quickly in areas with less than 12 hours of radiation than when planted in more than 12 hours of radiation (Valio and Rocha, 1977). The leaves' highest stevioside content occurred just before flowering, while the maximum dry weight was obtained at the flowering stage. Based on these facts, the first harvest was carried out during the period between the plants starting to flower and during flowering (Sumida, 1980) or two (2) months (8 weeks after planting) after planting the seeds in the field.

Meanwhile, Eli Afrida (2005) also stated that plant spacing on shallot also significantly affected the wet weight per sample of both wet and dry. The ideal plant spacing is a spacing suitable for the development of the upper plants, and there is sufficient space for root growth in the soil. Improper plant spacing will lead to competition to get several growth factors such as nutrients, light, air, and water. The denser plant spacing causes an increase in plant

\footnotetext{
${ }^{3}$ Indonesian Spices and Medicinal Crops Research Institute (ISMCRI).
} 
height. It is suspected to be the cause of plant competition for light. Plans competition in getting light causes the etiolation process due to the narrow growing space. There was a significant effect on observing the stevia's height aged 46 DAP with dense plant spacing, whereas clones affected plant height at 28 DAP and 46 DAP and the number of leaves at 46 DAP. Plant spacing, varieties, and interactions did not affect dry leaf weight and dry leafless stover at 46 DAP (Table 1).

Table 1 - Central Squares Random on Some Growth Parameters and Stevia Yields (Stevia rebaudiana Bertoni L.) in EG Cobanrondo, Malang

\begin{tabular}{|c|c|c|c|c|c|c|c|c|c|c|c|}
\hline \multirow[t]{2}{*}{ SK } & \multirow[t]{2}{*}{ DB } & \multicolumn{4}{|c|}{ PLANT HT. $(\mathrm{cm})$} & \multicolumn{2}{|l|}{$\begin{array}{l}\text { CANOPY } \\
(\mathrm{cm})\end{array}$} & \multirow{2}{*}{$\begin{array}{c}\text { NUMBER OF } \\
\text { BRANCHES } \\
\text { /plant } \\
46 \\
4 \\
\text { (DAP) } \\
\end{array}$} & \multirow{2}{*}{$\begin{array}{l}\text { NUMBER OF } \\
\text { LEAVES } \\
\text { /plant } \\
46 \\
\text { (DAP) }\end{array}$} & \multirow{2}{*}{$\begin{array}{c}\text { DRY LEAF } \\
\text { WEIGHT } \\
\text { (g/plant) } \\
46 \\
\text { (DAP) }\end{array}$} & \multirow{2}{*}{$\begin{array}{c}\text { LEAFLESS DRY } \\
\text { STOVER WEIGHT } \\
\text { (g/plant) } \\
46 \\
\text { (DAP) }\end{array}$} \\
\hline & & $\begin{array}{c}14 \\
\text { (DAP) }\end{array}$ & $\begin{array}{c}28 \\
\text { (DAP) }\end{array}$ & $\begin{array}{c}46 \\
\text { (DAP) }\end{array}$ & $\begin{array}{c}14 \\
\text { (DAP) }\end{array}$ & $\begin{array}{c}28 \\
(\mathrm{DAP})\end{array}$ & $\begin{array}{c}46 \\
\text { (DAP) }\end{array}$ & & & & \\
\hline REPETITION & 2 & 1.6 & 2.0 & 0.3 & 2.6 & 3.6 & 0.3 & 0.3 & 37.3 & 0.2 & 0 \\
\hline TREATMENT & 3 & 5.9 & 13.4 & 38.6 & 2.4 & 17.2 & 11.3 & 5.8 & 249.6 & 0.1 & 0.1 \\
\hline $\begin{array}{c}\text { PLANT } \\
\text { SPACING (PS) }\end{array}$ & 1 & 0.3 & 0 & $40.3^{*}$ & 1.3 & $44.1^{*}$ & $33.3^{*}$ & 5.3 & 12.0 & 0 & 0.3 \\
\hline CLONS (C) & 1 & 12.0 & $40.3^{*}$ & $75^{*}$ & 3 & 6.8 & 0.3 & 0 & $560.3^{*}$ & 0 & 0 \\
\hline $\mathrm{PS} \times \mathrm{C}$ & 1 & 5.3 & 0 & 0.3 & 3 & 0.8 & 0.3 & $12.0^{*}$ & 176.3 & 0.2 & 0.03 \\
\hline RANDOM & 6 & 2.1 & 0.5 & 1.5 & 1.7 & 2.0 & 1.5 & 1.1 & 40.9 & 0.2 & 0.03 \\
\hline TOTAL & 11 & 27.2 & 56.2 & 15.6 & 14 & 74.5 & 47 & 24.5 & 1076.4 & 0.7 & 0.43 \\
\hline $\mathrm{KK}(0 \%)$ & & 7.3 & 2.3 & 2.5 & 9.5 & 7.9 & 4.7 & 6.32 & 6.5 & 13.1 & 4.3 \\
\hline
\end{tabular}

Description * ${ }^{*}$ real at the Duncan test level of $5 \%$.

Stevia rebaudiana Bertoni is a secular plant that can easily collapse or be broken by wind and rain. An effort to overcome this is to closely adjust the plants' spacing because each plant can support each other (Sumida, 1980). Plant spacing and plant density per unit area will affect production and maintenance work in the garden. Also, there is a cover of the soil surface at the tighter spacing by the canopy's growth, saving the land from erosion so that nutrient loss can be suppressed and provide better micro conditions.

So far, to plant stevia in gardens, with a plant spacing of $25 \mathrm{~cm} \times 25 \mathrm{~cm}$ or $30 \mathrm{~cm} \times 30$ $\mathrm{cm}$ with a distance of $60 \mathrm{~cm}$ to $70 \mathrm{~cm}$ for every four (4) rows of plants, is quite suitable because it provides enough space for workers in the garden. It also avoids trampling, and plants in the middle can be reached during maintenance (Tirtoboma, 1983). Furthermore, in California, it was reported that planting with a density of 80,000 plants/ha resulted in many plants' death. Meanwhile, the density of more than 40,000 plants/ha (plant spacing of $25 \mathrm{~cm}$ x $25 \mathrm{~cm}$ ) did not increase the profit (Shock, 1982). According to Sumida (1980), high yields were obtained in populations between 833 and 4000 plants $/ 100 \mathrm{~m}$.

On other commodities, such as jatropha, Dedi Soleh et al. (2007) state that a wide plant spacing $(2 \mathrm{~m} \times 4 \mathrm{~m}$ or $2 \mathrm{~m} \times 6 \mathrm{~m})$ required in intercropping practice will provide sufficient space for the main and intercrops' growth. Lilik (2009), on the commodity Sorghum bicolor, reported that plant spacing had a significant effect on growth, carbohydrate content in stems, and biomass of sorghum seeds but had no significant effect on carbohydrate content in seeds. The same opinion was also stated by Ban et al. (2009), Dean et al. (2011), Dantata (2014), Fanadzo et al. (2010), Hoshang (2012), Lashkari et al. (2011), Mohseni (2013), and Getachew et al. (2013).

Afrida (2005) states that plant spacing on shallot also significantly affects the sample wet weight of shallot and the yields. Other researchers also found similar results (Gulluoglu and Arioglu., 2009; Getachew et al., 2013; Zebarth et al., 2006; Akbarinia et al., 2006; Masood et al. 2004, Heidari et al. 2008; Baldwin and Wesley., 2006; Lebaschy et al., 2008). Furthermore, the research results of Githunguri et al. (2009) indicated that plant spacing affected plant height. At a plant spacing of $2 \mathrm{~m} \times 2.5 \mathrm{~m}$, jatropha produces a height of 6.90 $\mathrm{cm}$, which is shorter than when planted at the plant spacing of $4 \times 2 \mathrm{~m}$ with a height of 27.2 $\mathrm{cm}$ at the age of 3 months (Gimplinger et al., 2008; McMaster et al., 2012; Beg et al., 2007; Kazemeini et al., 2009; Ibrahim et al., 2009). 


\section{CONCLUSION}

The results show that plant spacing affects plant height at 46 DAP, canopy width at 28 and 46 DAP. Narrow plant spacing produces taller plants than that wide plant spacing. Clones affect plant height at 28 DAP and 46 DAP and the number of leaves at 46 DAP. Plant spacing, varieties, and interactions do not affect dry leaves weight and leafless stover weight at 46 DAP. Thus, the cultivation of stevia clones, both narrow-leaf and wide-leaf, is recommended at a narrow spacing.

\section{ACKNOWLEDGEMENTS}

Our gratitude goes to Mr. Dr. Bambang Heliyanto and Mr. Dr. Djumali, who has helped and directed this research.

\section{REFERENCES}

1. Afrida, A. 2005. Efektivitas penggunaan pupuk organik $A 32$ and jarak tanam terhadap pertumbuhan and produksi tanaman bawang merah (Allium ascalonicum.L.) varietas Brebes. Jurnal Penelitian Bidang Ilmu Pertanian Volume 3, Nomer:1, April 2005 (kptapr2005). diakses pada tanggal 12 Februari 2013.

2. Akbarinia,A., Daneshian,J.,\&Mohammadbiegi,F.2006. Effect of nitrogen fertilizer and plant density on seed yield, essential oil and oil content of Coriander (Coriandrum sativum L) Iranian Journal of Medicinal and Aromatic Plants. Vol 22.No.4.410-419.

3. Beg, A., Pourdad, S.S., Alipour, S., 2007. Row and plant spacing effects on agronomic performance of sunflower in warm and semi-cold areas of Iran. Helia, 30 (47), 99-104.

4. Ban, D., Zanic, K., Dumicic ,G.,Gotlin, C.T., and Goreta, B.S.2009. The type of polyethylene mulch impacts vegetative growth, yield, and aphid populations in watermelon production. J.Food Agric.Environ.7: 543-550.

5. Baldwin,B.\& Wesly,J, 2006. Population density and row spasing effets on dry matter yield and bark content of kenaf (Hibiscus cannabinus L.).Industrial Crops and Products ,23,244-248.

6. Dantata.,2014. Assessing watermelon cultivars under different planting distances in Bauchi North, Nigeria.Asian J. Appl.Sci.2(3): 381-386.

7. Dedi Soleh Effendi, S. Taher, and W. Rumini. 2007. Pengaruh tumpangsari and jarak tanam terhadap pertumnbuhan and hasil tanaman jarak pagar (Jatropha curcas L.). Pusat Penelitian and Pengembangan Perkebunan, Bogor. diakses tanggal 8 Februari 2012.

8. Dean, B., Smiljana, G.B., Milan,O., Josipa, H.,Bruno,N., Katja,Z. and Dragan .,2011. Growth and yield response of watermelon to in-row plant spacings and Mycorriza.Chilean.J. Agric.Rs.71(4).

9. Elli Afrida, 2005. Efektivitas penggunaan pupuk organic A32 and jarak tanam terhadap pertumbuhan and produksi tanaman bawang merah (Allium ascalonicum.L.) varietas Brebes. Jurnal Penelitian Bidang IImu Pertanian Volume 3, Nomer :1,April 2005 (kptapr2005). diakses pada tanggal 12 Februari 2013.

10. Fanadzo M., Chiduza C., Mnkeni P. N. S. 2010: Effect of inter-row spacing and plant population on weeddynamics and maize (Zea mays L.) yield at Zanyokwe irrigation scheme, Eastern Cape, South Africa. African Journal of Agricultural Research. 5. (7) 518523.

11. Gimplinger, D., Schulte, G., Dobos, G., and Kaul, H. 2008. Optimum crop densities for potential yield and harvestable yield of grain Amaranth (Amaranthus cruentus) are conflicting. Europe Journal Agronomy, 28, 119-125.

12. Githunguri, A.O.Esilaba and L.M.Mutuku. 2009. Effect of spacing on Jatropha curcas planted in semi-arid, Eastern Kenya, P.O.Box 340, Machakos. 
13. Getachew T, Derbew B,Solomon T.,2013:" Combined effect of plant spacing and time of earthing up on tuber quality parameters of potato (Solanum tuberasum L) at Degem District, North Showa Zone of Oromia Regional State" Asian J.Crop Sci.5(1):24-32.

14. Gulluoglu L, Arioglu H.,2009 .Effects of seed size and in-row spacing on growth and yield of early potato in a Mediterranian-type environment in Turkey. Afr. J. Agric. Res. 4(5): 535-541.

15. Heidari, F., Zehtab,S.,Javanshir ,A.,Aliari,H.,\& Dadpoor,M.2008. The effetcs of application microelements and plant density on yield and essential oil of peppermint (Mentha piperata L.), Iranian Journal of Medicinal and Aromatics Plants,Vol.24,No.1, 1-9.

16. Hoshang R. 2012: Effect of plant density and nitrogen rates on morphological characteristic grain maize. Journal of Basic and Applied Scientific Research. 2. (5) 46804683).

17. Ibrahim HM, El-Genbehy MM. Response of some sunflower hybrids to different hill spacings and N-fertilization levels. Minufiya J Agric Res 2009; 34: 641-659.

18. Kazemeini, S.A., Edalat, M., Shekoofa, A., 2009. Interaction effects of deficit irrigation and row spacing on sunflower (Helianthus annuus L.) growth, seed yield and oil yield. African Journal of Agricultural Research, 4 (11):1165-1170.

19. Lebaschy, M., Bakhtiari, M., and Sharifi ,E.2008. The effects of plant density on growth indices of Safflower (Carthamus tinctorius L.) under Damavand dryland condition. Iranian Journal of Medicinal and Aromatic Plant,Vol.24, No.4, 444-454.

20. Lilik E. S. 2009. Pengaruh jarak tanam terhadap pertumbuhan and produksi Sorgum bicolor (L) Moench sebagai sumber karbohidrat, diakses tanggal 12 Februari 2013.

21. Lashkari M., Madani H., Ardakani R. M., Golzardi F., Zargari K. (2011): Effect of plant density on yield andyield components of different corn (Zea mays L.) hybrids. AmericanEurasian Journal of Agricultural \& Environmental Science. 10. (3.) 450-457.

22. Masood,A.,Syed Asghar, H.,Mohammad,Z.,\&Abdur.R.2004.Effect of sowing season and row spacing on seed production of fennel (Foeniculum vulgare)Journal of Biological Science,7(7), 1144-1147.

23. McMaster, G.S., Buchleiter, G.W., Bausch, W.C., 2012. Relationships between sunflower plant spacing and yield: importance of uniformity in spacing. Crop Science, 52 (1), 309-319.

24. Mohseni M., Sadarov M., Haddadi H. M. (2013): Study of tillage, plant pattern and plant densities on kernel yield and its component of maize in Iran. International Journal of Agriculture and Crop Sciences. 5. (15.) 1682 -1686.

25. SWA. 2012. Raja gula Indonesia timur keluhkan defisit gula nasional. (http://swa.co.id/listed-articles/raja-gula-indonesia-timur-keluhkan-defisit-gula-nasional).

26. Shock,C.C. 1982. Experimental cultivation of rebaudi's stevia in California. Agro. prog. Rep. 122 p.

27. Syarif, F. 1982. Stevia rebaudiana sebagai tanaman alternatif penghasil zat pemanis alami. skripsi. Jurusan Pengolahan Hasil pertanian. UGM. Yogyakarta.

28. Sumida,T. 1980. Studies on Stevia rebaudiana as a new possible crop for sweetening resource in Japan. J.Cent.Exp.Stn. 31: 1-71.

29. Tirtoboma, 1983. Konsep pemikiran tentang budidaya tanaman stevia rebaudiana Bertoni. Pertemuan reguler staf peneliti and teknisi BPP Bogor. Bogor.

30. Valio, I.F.M and R.F. Rocha. 1977. Effect of photoperiod and growt regulator on growth and flowering of Stevia rebaudiana Bertoni. Jap. J. Crop Sci. 46 (2):234-248.

31. Yusmaini, F. and T.K.Suharsi. 2008. Pengaruh Jenis Bahan Stek and Penyungkupan terhadap Keberhasilan Stek Stevia (Stevia rebaudiana Bertoni M.). Makalah Seminar Departemen Agronomi and Hortikultura. IPB. Bogor.

32. Zebarth BJ, Arsenault WJ, Sanderson JB.2006. Effect of seedpiece spacing and nitrogen fertilization on tuber yield, yield components, and nitrogen use efficiency parameters of two potato cultivars. Am.J.Potato.Res 83(4):289-296. 